\title{
Chapter 13: Quantifying the Costs and Benefits of Change: Towards A Methodology
}

\section{Christine Smith}

\section{Introduction}

As outlined in previous chapters of this book, the current state of evolution of Australia's system of federation has been the subject of considerable criticism in recent years. This chapter narrows in on those criticisms that focus on economic factors, including the assignment of expenditure responsibilities and revenue raising powers between the federal, state and local levels. It also recognises the emergence of new regional governance and service delivery arrangements and speculates on the capacity of these arrangements to act as an alternative to more substantive change in other elements of the system. The purpose of this chapter is not to provide answers as to whether or not change to current federal structures and/or financial arrangements will generate net economic benefits. The aim here is to point to some key directions in which debates surrounding federalism and regionalism need to move, to permit the development of a more appropriate analytical framework for generating such answers.

In the next section, various calls for change based on economic rationales are documented, and the case is made for a shift in focus to the functions to be carried out by the various levels of government in order to address these concerns. In the third section of the chapter, the relevant public finance literature is reviewed for insights into potential reform principles. In section 4, attention shifts to the literature on the economics of local government amalgamation, since reform agendas that have been popularly espoused in the past have either explicitly or implicitly involved a reduction in the number of units at this level. In section 5, previous attempts at identifying the net economic benefits to be derived from various proposed reforms are evaluated and suggestions made as to how their methodology could be improved. The chapter concludes with directions that should be pursued for the sound economic evaluation of potential change agendas, based on a more detailed initial set of representative change proposals. 


\section{Change agendas and the need for a focus on functions by level}

Recent calls for change in federal-state arrangements, based on economic rationales, include the following (emphasis mine):

Australia's federation needs new life breathed into it for the benefit of the community and business. In just about every major policy area our approach to intergovernmental relations presents barriers and obstacles to getting sensible outcomes ... The time has come to take a more holistic approach to our system of intergovernmental relations so that our federation works for us rather than against us (Australian Industry Group 2005).

Where two levels of government are responsible for different parts of the same system it is difficult or impossible to achieve coordination in policy and funding ... Lack of coordination gives rise to significant overlaps and gaps ... with too much funding allocated to some types of service and not enough to others ... poor coordination of services in areas of shared responsibility creates major problems for customers, who become confused and frustrated in their efforts to deal with a multi-layered system that shuttles them back and forth (National Commission of Audit 1998).

Australia needs a summit on federalism ... Reform is overdue ... Instead of each tier exercising the powers that are most appropriate to it, we have governments prone to administrative duplication and buck passing. We also have a system where states cannot raise the money needed to provide the most basic services. Instead they rely on Commonwealth grants, an economic and political dependency that is neither healthy nor consistent with the best delivery of services to the community (Williams 2006).

Through most of our past quarter century or more of improving government performance, we have had endless buck-passing between the two most important levels of government - in education and training, health, infrastructure, water management and other important issues. The States depend on the Federal Government for funding, Canberra relies on the States for implementation - and each relies on the other for deflecting accountability ... Only by finally fixing federal state-relations will we truly become the world leaders in public policy and economic development and be able to build on our quality of life (Devenson 2006).

Common themes that emerge are those of overlap and duplication across various functional areas and the need for greater clarification of responsibilities, as well 
as the need for thought to be give to the reassignment of some areas of responsibility from federal to state governments and vice versa.

Recent calls for change in federal-state-local arrangements have been even stronger, recognising the inadequate level of revenue flowing through to local governments relative to the growing importance and array of functions for which they have become responsible. These criticisms are demonstrated elsewhere in this book (see Brown, Head, Bell, and Wiltshire this volume). Other such calls include:

Getting better results out of areas where Federal-State activities intersect is vital. Inconsistencies, duplication and additional costs associated with poorly coordinated or conflicting State-Federal (and local) government policies and regulations affect virtually every area ... (Access Economics 2004).

Cost shifting is, ultimately, a symptom of what has become dysfunctional governance and funding arrangements. It is time to combine the best efforts of governments and choose a better way. There have been many demands for the three spheres of government to work more closely and eliminate duplication and wasted resources. In a shrinking and increasingly competitive world, the luxury of three spheres of government, with often different agendas, in a country of nearly 20 million people is straining our resources (House of Representatives Standing Committee on Economics, Finance and Administration 2003).

The problem of over-government has long been identified, and the solution offered is the same: the abolition of the States ... they no longer manage their affairs in their own way ... most of the power to do that has already leached back to the Commonwealth through its control of the purse strings...its not going to flow back ... yet though states' rights are outdated, the States are entrenched facts ... reformers should seek to economise elsewhere - in the third tier, local government ... NSW comprises an intricate patchwork of tiny fiefdoms. Nearly 40 councils run services for one city - Sydney. Though some share services, the unnecessary duplication is a drain on resources ... The amalgamation of local councils should be the first step towards a two-tier system of government in Australia (Sydney Morning Herald 2006).

Recognition that important areas such as natural resource management and economic development may be better dealt with at a level that crosses current local (and, in some cases, state) boundaries has led to the emergence of an ever-expanding array of regional bodies. Such bodies could be argued to comprise a fourth (fifth, sixth, etc.) tier within the federal system. Some writers point to these bodies as a vehicle via which existing formal levels of government can 
cooperate and thereby eliminate the need for more radical reform of the current federal system (Business Council of Australia 2006; Dollery, Johnson et al 2005; Dollery, Marshall et al 2005; Marshall et al 2003). However the costs associated with these bodies have not been fully documented and neither have the benefits of their achievements relative to their costs. More substantively there has emerged a set of concerns about these regional arrangements that deserve further serious investigation before they could be seen as a viable way forward. For example:

a. Beer et al (2003) highlight empirical research pointing to regional bodies afflicted by inadequate organisational size, low (usually non-existent) recurrent funding, 'third world'-style birth and death rates, poorly directed central funds and duplication and coordination problems between and within governments;

b. the Regional Business Development Panel (2003) reported:

We were struck by the sheer number of (organisations) operating at a regional level with the objective of supporting regional and business development ... There is overlap, duplication and at times competition between the layers of government ... There are too many bodies trying to achieve common outcomes for the same area. As a result public money is spread too thinly and resource-starved organisations spend considerable time chasing additional funding... One region we visited has around 20 different development agencies, employing around 40 people. Five are Commonwealth bodies, five are state organisations, local government runs seven and business groups manage the rest ...

c. and the Regional Implementation Working Group (2005) recommended with respect to natural resource management (NRM) that:

... the Australian and State/Territory governments clarify and articulate their respective roles and responsibilities in regard to the provision of support for regional NRM bodies ... and determine the base level of core funding required to maintain an appropriate corporate governance framework to enable a regional body to meet conformance, performance and administrative requirements ...

The themes that emerge in this area suggest that hopeful initiatives at non-traditional scales of policy and governance have tended to be unsupported by legal, administrative, financial, relevant professional expertise or other capacity. They also tend to rely excessively on the time of volunteers and to be short-lived when they fail to live up to expectations or when policy fashions change. 
With such widespread dissatisfaction with various elements of the current system, it is not surprising that recent public opinion surveys by Brown and his colleagues indicate that the majority of residents in Queensland (Brown 2002a, b) and New South Wales (Brown et al 2006; Gray and Brown this volume) prefer a scenario different than the current system. In particular, a two tier system based on regional governments is the single most preferred option in both cases. Unfortunately, as yet the pilot research in this field has not provided details of the various options for change presented to respondents prior to asking them to rate these options; rather, broad descriptors were provided such as 'same system as today', 'three-tiered, more states', 'two-tiered, regional governments', and 'four-tiered'.

This is not surprising since a scan of the relevant literature reveals multiple reform agendas, albeit with scant details on the specifics (Jaensch 2003). There are calls for the abolition of states and a move to a two tier system of government, but no consensus on what replaces them at the sub-national level (e.g. how many regional governments, with what boundaries, which current state government expenditure responsibilities and taxing powers would divert to the Commonwealth and which would be assigned to the new regional governments, and the system to be put in place to ensure horizontal and vertical fiscal equalisation). Similarly, there are calls for new states, but no consensus on how many or where they would be located. There are calls for local government amalgamations, but no consensus on which ones or on what criteria they might be selected. There are calls for a new or reformed set of regional institutions, but not what powers, functions, resources or reporting mechanisms they would be given from whom.

In order to move the debate on from speculation by a broad range of well-meaning reformers, consensus needs to be developed around a concrete reform agenda (or small set of such agendas). More importantly, however, in order for such agendas to be developed in a way that net costs or savings from change can be estimated, details are required with respect to how the functions of government would be distributed in any one of these agendas. That is, to be able to be costed, any given scenario needs to specify what functions (or components of functions):

a. currently exclusively federal, state or local would be better assigned to other level(s);

b. currently overlapping in terms of responsibility would be better allocated to a single level exclusively;

c. necessarily overlapping but in need of better co-ordination between levels to avoid duplication; and

d. fall between gaps with our current levels of government leading to the need for formation of regional bodies. 
A substantial amount of relevant data is available in the Australian context at a functional level of disaggregation that would provide insights into an analysis aimed at providing such details - for example, from government finance statistics and from State and Federal Government Grants Commission reports. It is important to recognise, however, that when advocating revised assignment of expenditure responsibilities between levels of government, it is necessary to also address the machinery for shifting taxation and other forms of revenue sources necessary to carry out these responsibilities.

\section{Insights from fiscal federalism literature}

The fiscal federalism literature provides some useful principles that could be invoked when fleshing out alternative reform agendas and, in particular, the proposed (re)assignment of functions (expenditure responsibilities and taxing powers) between levels of government. These principles relate to: expenditure responsibilities; taxation powers; and intergovernmental grants.

\section{Expenditure responsibilities}

The first principle that deserves mention is that of subsidiarity, which has been interpreted in a federal system of government as implying that provision of goods and services should be administered at the lowest level feasible within the national interest (see Brown 2002b; Brown, Podger, Head this volume; Access Economics 2004; Twomey and Withers 2007). The rationale appears to be that this permits such provision to most closely match the preferences of the people.

The second principle to emerge is that of correspondence, which argues that where consumption or use of a particular good or service is limited to the boundaries of a particular jurisdiction, then its provision should be allocated to a sub-national government whose boundaries are defined by the spatial benefit (or market area) boundaries associated with this good or service (Oates 1972, 2005; Warren 2005; Williams 2005b). The resulting allocation generates economic efficiency since it allows for a matching of local demand and supply, with voters able to move between jurisdictions in search for an optimal mix of provision and associated taxes and charges given their individual needs. An obvious difficulty confronted when putting flesh around this principle is that, carried to the extreme, each good or service provided by governments could conceivably have a different set of spatial benefit (or market area) boundaries leading to a need for a multitude of overlapping levels of government (Access Economics 2004; Productivity Commission 2005, 2006). Clearly, common sense is needed when interpreting this principle if only three (or at most four) levels of government are being considered.

The third principle involves giving due recognition to economies of scale in the provision of goods and services, with a case generated for movement of provision to a higher level where it costs less if produced or provided by single jurisdiction 
rather than separate smaller ones (Access Economics 2004; Williams 2005b). It has been argued more recently that possibilities for separation of production from provision should be exploited where feasible, since this may permit provision to be retained with smaller units, while at the same time allowing them to take advantage of mutually agreed co-operative production arrangements at a scale sufficiently large to generate maximum cost savings (Dollery 2005 b,c).

The fourth principle recognises the constraints imposed by existing jurisdictional boundaries and argues for the need for a mechanism to resolve inter-jurisdiction spill-overs or spill-ins of benefits (and/or costs) of a particular good or service. In the absence of such mechanisms, economic inefficiency in the form of under(or over-) provision of such goods or services would result. The case is thereby created for responsibility for these goods or services to be either transferred to a higher level of government, or for it to remain at the lower level but for intervention by a higher level through system of tied grants aimed at providing 'compensation' to those lower level jurisdictions disadvantaged by the nature of the observed spill-overs (or spill-ins). The tied grant solution is preferred where location-specific or individual-specific cost differences occur between jurisdictions and/or where economies of scale are exhausted at comparatively low population levels and/or geographic spreads (Oates 1972, 2005; Productivity Commission 2005, 2006).

The fifth principle recognises that inter-jurisdictional differences in the nature, cost and/or level of provision of particular goods or services could generate negative impacts on the mobility of factors of production, resulting in economically inefficient locational choices. The literature suggests that where significant transaction costs are imposed on labour or firms from movement across jurisdictions, then a case can be made for minimum standard setting at higher levels and the introduction of a system of compensating grants for lower level jurisdictions for which this imposes cost increases (National Commission of Audit 1996; Productivity Commission 2006).

The final principle suggests that accountability is strengthened if responsibility for a particular function is tier-specific (Brogden 2006; National Commission of Audit 1996; OECD 2006; Selway 2001). For many important functions this is not a realistic option, with most analysts acknowledging that assignment of responsibilities will most often resemble a marbled not a tiered cake (see Wiltshire this volume). What is necessary, then, is to ensure that the nature of this marbling is not randomly generated but rather emerges from a process of careful deliberation (and is the subject of periodic renegotiation as economies of scale and other characteristics of production or provision change over time). If expenditure responsibility in a broad area (e.g. education or health) is necessarily shared, then respective roles in segments of this area need to be agreed and mutually understood, with cooperative arrangements put in place to ensure 
appropriate ongoing coordination between these segments to ensure they mesh well together at key transition points (Warren 2006; Wilkins 2004).

\section{Taxation powers}

The principle of fiscal equivalence implies that each level of government should finance its assigned functions with funds it raises itself. However carried to extreme this would lead to significant inefficiencies in tax collection from many revenue sources and distortions to locational choices of individuals and firms. The latter concern has also led to arguments suggesting that taxes on highly mobile tax bases should be allocated to higher levels of government, as should taxes on tax bases that are uneven across jurisdictions (Access Economics 2004; Dahlby 2001; Productivity Commission 2006).

The resulting lack of alignment of expenditure responsibilities and tax assignments leads to a situation of vertical fiscal imbalance - where revenue raising capacity of at least one level of government exceeds its expenditure needs whilst the reverse is the case for the other levels. In general there is support for tax sharing rather than reassignment of tax bases and rate schedules in this situation, implying the need for a system of intergovernmental transfers or grants. Such a system needs to be managed carefully - in particular, a high level of autonomy over expenditure priorities and service management is required by the recipients in order to ensure that the efficiency benefits of competitive federalism are not constrained (Allen Consulting Group 2006; Grewel and Sheehan 2003; Hancock and Smith 2001; Saunders 2002; Warren 2006).

\section{Intergovernmental grants}

The current level of vertical fiscal imbalance in Australia has been a cause for concern, with the Commonwealth Government's revenue collections exceeding its expenditure needs by up to $40 \%$ (House of Representatives Standing Committee 2003). While transfer by the Commonwealth of GST revenues to the States has made significant inroads into addressing the latter's own-source revenue shortfalls, a similar arrangement remains elusive for local government (Access Economics 2004; Productivity Commission 2006).

Australia's current system of intergovernmental grants includes horizontal fiscal equalisation (HFE) payments administered by the Commonwealth and various State Grants Commissions (Commonwealth Grants Commission 2006a, b; Local Government Grants Commission South Australia 2005, New South Wales Local Government Grants Commission 2005, Northern Territory Grants Commission 2005, Queensland Local Government Grants Commission 2005, Tasmania State Grants Commission 2005, Victoria Grants Commission 2005, Western Australian Government Grants Commission 2005). These payments are aimed at ensuring that jurisdictions at each sub-national level of government receive funding from the Commonwealth, such that if each made the same effort to raise revenue from 
its own sources and operated at the same level of efficiency, then each would have the capacity to provide services of the same standard to their constituents (Morris 2002; Williams 2005a).

These HFE payments currently involve correction for disadvantage on both revenue and expenditure sides, but some concern has arisen over the efficiency effects of the latter (Hancock and Smith 2001; McLean 2004; Petchey and Levtchenkova 2004; Usher 1995). Nevertheless, various attempts at estimating the size of such efficiency effects have concluded that they are small, and possibly worth incurring for the gains they generate in terms of equity (Dixon et al 2002, 2005; Harding et al 2002; Williams 2005b).

Clearly there is a need to evaluate the implications of various change options for the magnitude and nature of both vertical and horizontal equalisation payments - with a recognition that the order of magnitude of such payments may need to involve both a one-off compensation for past inadequate service provision in some newly emerging jurisdictions, and a steady state set of payment schedules for such jurisdictions in the future.

\section{Insights from local government amalgamation literature}

As mentioned earlier in the chapter, there exists a widespread notion in both the popular media and government and business reports that economies of scale exist in the provision of goods and services within the level of local government, such that economic benefits can be derived from the elimination of numerous small local government authorities through a process of amalgamation (forced or voluntary). It is also widely assumed that attempts to redress the poor financial position of this level should await resolution of this structural problem (Business Council of Australia 2006; Department of Transport and Regional Services 2005; House of Representatives Standing Committee 2003; State Chamber of Commerce (NSW) 2005; Sydney Morning Herald 2006).

In addition, many of the more radical proposals for reform of the federal system involve the elimination of the current state and local levels of government and their replacement by a single regional level of government (e.g. Hall 1998; Soorley 2004). This in turn implies both the devolution of most, if not all, current functions allocated to the States to the new regional level, and the amalgamation of a large number of the current local government authorities into larger regional units. It is of considerable interest then to examine the empirical evidence available relating to the economics of local government.

Overseas empirical evidence suggests that while total costs do vary with population size, it is not the case that a decreasing cost curve prevails for all population sizes (Byrnes and Dollery 2002; Dollery and Fleming 2005). That is, while there is evidence that costs do decrease up to a certain population size, after this point these costs generally begin to rise again - with suggestions that 
for large metropolitan areas the best solution is for a body charged with ensuring co-ordination of policy and implementation across key areas (such as transportation systems) but that this body be complemented by a series of smaller local government units responsible for ongoing service delivery (Sancton 2005). In addition, the results of various studies point to the population range associated with the lowest per capita costs being different depending on the type of service being investigated. This in turn highlights the fact that much of the overseas research in this area is of limited relevance to the Australian context, since local governments in our federal system have responsibility for a different range of services than those in other countries - for example, police and schools in the United States and public housing in the United Kingdom.

Empirical evidence from Australia is extremely limited in terms of volume, and mixed in terms of its results. However the majority of studies conducted to date suggest an 'optimum size' from an economic viewpoint as in 30-80,000 population range (Byrnes and Dollery 2002; Marshall 1998; Soul and Dollery 2000; Soul 2000) - a size exceeding many of our current local government jurisdictions. At the same time, the results obtained from these empirical studies have been criticised (Allen 2003; Dollery and Crase 2004; Dollery, Crase et al 2005; Woodbury et al 2002) for ignoring the variable nature of local government services and the presence of differentiated economies of scale - a fact confirmed from a detailed reading of the reports of the various state grants commissions referred to above as well as by studies focussing on particular local government services (for example, Worthington and Dollery 2000; Woodbury et al 2002). Labour intensive customer-oriented services would generally be expected to generate lesser economies of scale than capital intensive services (such as water and sewerage) where benefits can be obtained from spreading fixed costs across a larger number of service points (Dollery and Fleming 2005).

Many of the empirical studies conducted based on the Australian experience have also been criticised for employing single- rather than multi-variate analysis with omitted variables (demographic/geographic characteristics) such that the true impact of population size has, in general, been overestimated (Byrnes and Dollery 2002). It is not surprising then that local government grants commissions introduce variables such as population density, remoteness, ethnicity, indigenous status, age structure, non-resident service provision, climate and terrain into their analysis of the appropriate size of their equalisation grants, rather than distributing them on a strict per capita basis (Department of Transport and Regional Services 2005). This in turn suggests that the optimal size of a local government jurisdiction may differ for rural and remote communities than those based around provincial centres and metropolitan areas (Soul and Dollery 2000), but investigation of this hypothesis in a rigorous manner has yet to be undertaken. 
Given the mixed results and the methodological flaws discussed above, it is not surprising that evaluations conducted post-amalgamation have almost invariably reported that the economic benefits actually experienced have been considerably lower than those estimated by the proponents of the change prior to amalgamation (Allen 2003; Dollery, Crase et al 2005) - and that this experience has been replicated overseas as well (Dollery, Keogh et al 2005; Frontier Centre for Public Policy 2003; Rouse and Putterill 2005). This in turn has led to some commentators suggesting that alternative means exist for achieving economies of scale in key functions without amalgamation (eg. ROCs, strategic alliances for joint provision, tendering) (Dollery 2005a; Dollery and Crase 2004; Dollery, Crase et al 2005; Dollery and Johnson 2005). However, little if any evaluation has been conducted with respect to the cost effectiveness of these alternative arrangements.

\section{Previous attempts at evaluating net benefits of change}

Alongside this specific, albeit incomplete, research into the economics of current structures of governance, some effort has been made to estimate the full range of net benefits that might be expected to be derived from reform of the federal system. Numerous government publications, consultancy reports, popular media analysts and non-economics academic papers quote various estimates made by Drummond as to the costs of duplication and coordination inherent within the current federal structure (for example, Access Economics 2004; House of Representatives Standing Committee 2003; Parliament of Victoria 1998). These estimates vary from $\$ 10-\$ 40$ billion dollars per annum, depending on which calculation is chosen for quotation. The most often quoted figure, however, is the $\$ 20+$ billion claimed to be able to be saved from moving to a two tier system that abolishes the States (Drummond 2002).

By contrast, a study commissioned by state and territory governments, which focuses only on the direct and indirect overlap costs associated with special purpose payments, argues that the cost savings are more like \$1 billion (ACIL Economics and Policy Pty Ltd 1996; Tredbeck and Cutbush 1996). A more recent study using Commonwealth Grants Commission data produces a similar order of magnitude estimate, namely $\$ 0.8 \mathrm{~m}$, for the cost of overlap and duplication between the Commonwealth and state levels (Garnaut and Fitzgerald 2002; Allen Consulting Group 2006). Yet another recent report estimates these costs to be $\$ 8.92$ billion (Access Economics 2006).

These are vastly different estimates, suggesting the need for a careful examination of the underlying methodologies in order that we might be able to move towards development of a framework capable of resolving these differences and in so doing get a better handle on the real order of magnitude of potential savings (and/or costs) from various reform options. This is especially important given flaws inherent in the Drummond and Access Economics (2006) approaches, and 
the narrow focus of the alternative estimates. Some of these flaws have already been commented on by others (e.g. Twomey and Withers 2007).

Drummond's $(2001,2002)$ approach commences with the assumption that government expenditure associated with any jurisdiction can be divided into a fixed cost component and a single variable cost component. The single variable cost component is calculated as a function of the aggregate population level in the jurisdiction; while the fixed cost component is assumed to be associated with overheads or administration of the level of government in question, and hence able to be avoided or eliminated if this level of government is phased out. Since the variable cost component is solely a function of population levels, it is argued that such costs will remain unaltered in magnitude should responsibility for that population shift to another jurisdiction. The sizes of these two components are estimated by fitting a simple linear regression model to pooled time series/cross-section data relating to three consecutive years (1998-99 to 2000-01) and eight jurisdictions (states and territories) - that is a total of 24 observations. The derived regression equation is:

$$
\mathrm{E}=1.5883+6.6152 \mathrm{P}
$$

where $\mathrm{E}=$ total public sector expenditure ( $\$$ billion in 2000-01 dollars), and $\mathrm{P}$ $=$ population (in millions).

The fixed cost estimate is $\$ 1.5883$ billion and the variable (or marginal) cost estimate is $\$ 6,615$ per head of population. It is this fixed cost estimate which it is argued to be saved if a particular jurisdiction is merged with another. Abolition of seven of the eight States (with the remaining one absorbing the responsibilities of those abolished and in effect administered by the Commonwealth) is argued to yield cost savings of seven times the fixed cost estimate - namely \$11.12 billion (= $7 \times 1.5883)$. Drummond also assumes that individual state deviations around the estimated regression line were accounted for by higher or lower variable costs per head of population and hence able to be eliminated through horizontal amalgamation. An algorithm was developed for achieving these mergers in ascending population size order. Application of this algorithm resulted in an almost doubling of the estimated cost savings from abolition of the States, namely $\$ 20.22$ billion.

A number of serious criticisms can be made with respect to this aspect of the Drummond approach:

a. 24 observations is too small a number of observations to support the findings reported, especially given the comparative lack of variability in the total level of government expenditure in any given jurisdiction over successive years and the use of pooled time series and cross sectional data - a longer time series of observations is available, even though the recent shift from 
cash to accrual accounting within government finance statistics may generate the need for care to be exercised in splicing relevant time series together;

b. The assumption of a single variable cost component based on population levels ignores a large volume of available data relating to determinants of inter-jurisdictional variations in costs. For example, federal and state grants commissions have long recognised in their horizontal equalisation grants that aggregate population size is only one relevant factor that needs to be taken into account when seeking to understand inter-jurisdictional expenditure requirements. Other factors of relevance include population composition, population dispersion, and geography including climate and terrain. Ignoring these other factors leads to an overestimation of the fixed cost component. In technical terms the regression equation is inappropriately specified due to omitted variables, such that at the very least there is a need to move to a multiple regression equation that includes other variable cost terms;

c. In Drummond's estimation the effects of all these other variable cost factors are being inappropriately attributed to the fixed costs component, leading to its overestimation. Given the importance of this fixed cost component to the remaining steps in the Drummond approach, this represents a serious problem;

d. While Drummond reports the coefficients related to his fixed and variable cost components, he does not report the associated standard deviations or $t$ test statistics, such that the statistical significance of his parameter estimates related to these two components cannot be determined. In addition he does not report results of any regression diagnostic tests conducted yet previous modelling experience in this area suggests that the equation as estimated has problems that require it to be re-specified and re-estimated in a different format. In particular, as other critics (Access Economics 2004; Parliament of Victoria 1998) have pointed out, it is more usual to estimate models relating to government expenditure in per capita terms because of serial correlation between total expenditure and population;

e. The assumption that functions carried out by a state government could be transferred to a national body without altering either the fixed cost or variable cost component is simply unrealistic. In particular it ignores the coordination costs that could be expected to result from attempts to manage population-oriented services such as education, health and policing from a single centralised location in a nation as large as Australia with its vast areas of sparsely dispersed populations. It also ignores research relating to economies/diseconomies of scale in provision of the services for which our state governments are currently responsible - which for many functions have resulted in regionalisation of service provision rather than the adoption of a one size fits all model within many states; 
f. The implied assumption that population is the only determinant of variable or marginal costs of service provision suggests, for example, that transfer of responsibility for providing state level services to a particular area within Queensland would not involve any increase in per capita costs if this provision was administered from say Perth rather than Brisbane. This is clearly unrealistic.

g. By using pooled time series/cross-section estimation the assumption is being made that all state governments host equal fixed and variable costs - so that amalgamation of any two states is argued to liberate cost savings equal to an identical quantum of fixed costs. This assumption too is unrealistic. For example it ignores the geography and demographic composition of the various states, as well as differences in the level and nature of the services that they currently provide in each major area of responsibility which would inevitably need to be bought into alignment following a merger. More significantly this assumption would be able to be dispensed with, if the regression exercise was to be redone with the underlying data collected over a longer time period;

h. The assumption that individual state deviations around the regression line were accounted for by higher or lower fixed costs and not higher or lower variable costs could also be readily tested via use of a more extended time series of expenditure data and the introduction of a series of dummy variables for the different states.

Drummond $(2001,2002)$ explored cost savings associated with change options other than abolition of the States, for example a new states option and an option that eliminated local rather than state governments were developed. However, the cost savings estimates derived were based on the same regression methodology underlying the abolition of the States option, and so most of the criticisms outlined above continue to apply. Some additional unrealistic assumptions were introduced when these options were explored. In particular:

a. the new states option assumed that data and associated parameter estimates derived from Tasmania would be representative of any new state likely to be introduced. This is patently not realistic given the geography, economy and demography of Tasmania compared with potential mainland new states (such as the New England region of NSW and the Northern regions of Queensland, as mentioned by Wiltshire, this volume).

b. the elimination of local governments option assumed that the Australian Capital Territory (ACT) could be regarded as representative of all other 'reformulated states' - on the basis that the ACT government performs a mixture of both state and local government options. Again this is simply not realistic given the geography, economy and demography of the ACT compared with the rest of Australia. The ACT, for example, has the vast 
majority of its population employed in the public sector on incomes significantly higher than the national average, it has only one major urban centre which was centrally planned and administered from its inception, and it covers a very small geographic area. The costs of local government service provision under these circumstances are vastly different to those in either major metropolitan areas or remote rural regions elsewhere in Australia.

Despite the problems inherent in the Drummond (2001, 2002) analysis, he did attempt to estimate the full range of net benefits that might be expected to be derived from reform of the current federal system. Accordingly, this work has provided a significant departure point for ongoing work and significant stimulation to further debate and more targeted research. In addition, most alternative estimates also suffer their own problems. Most of the alternative estimates that have been published focus on only a narrow subset of potential savings (e.g. from reducing the Commonwealth Government's reliance on specific purpose payments as a form of intergovernmental grants) and/or ignore the role of local governments in the federation.

The most comprehensive alternative analysis to date, by Access Economics (2006), focuses on a large range of possible categories of cost savings that could be argued as able to be derived from reform. These categories were classified into two groups: (a) costs associated with spending-related efficiencies (including cost of administering intergovernmental grants and costs of coordination across different levels of government when overlap of functions exists) estimated at $\$ 5.1$ billion, and (b) costs associated with taxation-related efficiencies (including the use of inefficient taxes by the States) estimated at $\$ 3.8$ billion.

However, in the Access Economics (2006) analysis, the dollar values placed on these various categories of costs have not been derived from detailed economic or statistical analysis but rather from a set of assumptions or educated guesses. For example $10 \%$ of the dollar amount associated with special purpose payments to the States is argued to be associated with states spending above the efficient level due to lack of adequate coordination and/or oversight by the Commonwealth. No justification is given for why $10 \%$ represented a reasonable assumption. Similarly it was assumed that $3 \%$ of the expenditure by states was on activities that represented 'overlap and duplication' with the Commonwealth. In arriving at this 3\% figure, no specific areas of overlap or duplication were identified or costed, nor was any insight provided as to why 3\% was a reasonable figure to select from the 99 other possibilities between one and 100. In terms of cost shifting, the area of pharmaceuticals and public hospitals was singled out, and state governments accused of shifting costs on to the Commonwealth in the order of $3 \%$ of Commonwealth expenditure in this area. Cost shifting in other areas or from the Commonwealth to states were ignored; and even in the restricted 
area of pharmaceuticals and public hospitals, no reasoning was provided to justify the selection of $3 \%$ rather than $2 \%$ or $5 \%$ or some other percentage. In addition, the focus of the Access Economics (2006) report was purely on inefficiencies argued to be associated with current federal-state relations - local government and various regional organisational arrangements discussed earlier in this chapter are not mentioned.

As a result, there remains considerable scope for further research in this area.

\section{Conclusion: towards a sound evaluation framework}

In moving forward from this point in terms of economic evaluation of potential change agendas, one could proceed with analysis of aggregate expenditure for each level of government and in so doing improve on the econometric methods employed in the Drummond type of analysis. However, using this approach it is difficult to accurately estimate possible costs and savings of reform with a detailed focus on the distribution of government functions (expenditure responsibilities and taxing powers), argued as necessary at the beginning of the chapter. Accordingly, examining the strengths and weaknesses of existing methodologies leads to a new preferred approach. Rather than continuing in the tradition of aggregate forms of analysis, a sounder approach would:

a. take a particular function, analyse the costs of current mode(s) of delivery across various levels of government, and then identify potential net cost savings from a small set of change proposals;

b. repeat this for a selected subset of functions at each level;

c. sum the results across this subset of functions to identify the order of magnitude of savings for each change proposal; and

d. develop a ranking of these change proposals on the criteria of net economic benefits.

Not all government functions need be the subject of detailed analysis in this approach. Rather, a case can be made for narrowing attention in the first instance to only major functions (that is, ones accounting for a significant proportion of total expenditure at any given level) or ones seen as problematic (that is, ones subject to potentially significant overlap and duplication problems or ones that have been suggested in the literature as possibly being assigned to the wrong level currently).

In order for the proposed approach to work well, the change proposals to be evaluated in the first instance also need to be reasonably detailed (in terms of number of levels of government, which levels of government, how many units at each level and ideally their rough geographic locations). This is reinforced by public debates, noted earlier, over the feasibility of options that eliminate both the current state and local government levels and replace them with a new set of regional institutions. In addition, the public finance and local government 
amalgamation literature reviewed in this chapter indicates that the costs of public sector service provision by any particular level of government depend significantly on the nature of the jurisdiction in which these services are provided. Changing the demographic composition of the jurisdiction, its geography and/or its economic base can have a significant impact on these costs. This in turn suggests that when working up potential change options for further evaluation, there is a need to be specific about the number and boundaries of units at each sub-national level within each of the options. An option with 30 regional institutions, for example, will generate different results than one with 60 regional institutions. New states emerging around major metropolitan regions and the peri-urban areas in their immediate proximity will generate different results than new states emerging based around rural/mining regions remote from their current state capitals, and so on.

A separate set of research questions needs to be addressed, therefore, to producing a set of change proposals that are sufficiently specific and grounded to be usefully costed. This involves its own debates, as shown by the controversy surrounding suggestions that local government amalgamations in New South Wales may be able to be based on the concept of eco-civic regions (Brunckhorst and Reeve 2006; Dollery and Crase 2004b). However the details of the tested scenarios can be changed and refined over time, and the economic evaluations recalibrated, so the initial set of change proposals need only to be representative of possible directions rather than set in stone.

The purpose of this chapter has not been to provide answers as to whether or not change to the current federal structure, and/or the financial arrangements underpinning it, will generate net economic benefits. Rather the aim has been to point to some key directions in which debates surrounding federalism and regionalism need to move, in order to permit a framework capable of providing such answers to be developed. In doing so, it is acknowledged that economic criteria are only one class of criteria having relevance to the reform of our systems of government. Clearly, however, economic criteria are important ones given the nature of the statements extracted for quotation at the start of the chapter. The aim of the proposed new approach is to enable identification of which types of change agendas can potentially reap net economic benefits and which seem most likely to generate net economic costs. With this sort of information to hand, change proposals can be better developed and refined, thereby enabling debate to progress to a level likely to lead to the achievement of the type of improvement to our federal system that recent public opinion surveys suggest is desired by the electorate. 
Federalism and Regionalism in Australia

\section{References}

Access Economics 2004, Commonwealth-State Funding of Local Government: An Assessment of Reform Proposals. Report prepared for Australian CEOs Group. Access Economics Pty Limited, Canberra.

2006, Appendix 2. The Costs of Federalism. Report by Access Economics Pty Limited for the Business Council of Australia. Access Economics Pty Limited, Canberra.

ACIL Economics and Policy Pty Ltd 1996, Costs of Overlap and Duplication Between Different Levels of Government. Institute of Public Affairs for State and Territory Governments.

Allen, P. 2003, 'Why Smaller Councils Make Sense.' Australian Journal of Public Administration 62(3): 74-81.

Allen Consulting Group 2006, Governments Working Together? Assessing Specific Purpose Payment Arrangements. Report prepared for Victorian Government, June.

Beer, A. et al. 2003, Developing Australia's Regions: Theory and Practice. University of New South Wales Press, Sydney.

Brogden, J. 2005, Practical Federalism. Accessible at http://www.nsw.liberal.org.au

Brown, A.J. 2002a, 'After the Party: public attitudes to Australian federalism, regionalism and reform in the $21^{\text {st }}$ century.' Public Law Review 13(3): 171-190.

2002b, 'Subsidiarity or subterfuge? Resolving the future of local government in the Australian federal system.' Australian Journal of Public Administration 6I(4): 24-42.

Brown, A.J., I. Gray and D. Giorgas 2006, ‘Towards a more Regional Federalism: rural and urban attitudes to institutions, governance and reform in Australia.' Rural Society 16(3): 283-302.

Brunckhorst, D. and I. Reeve 2006, 'A Geography of Place: Principles and Application for Defining Eco-Civic Resource Governance Regions.' Australian Geographer 37(2): 147-166.

Business Council of Australia 2006, Modernising the Australian Federation: A Discussion Paper. Business Council of Australia, Melbourne.

Byrnes, J. and B. Dollery 2002, 'Do Economies of Scale Exist in Australian Local Government? A Review of the Research Evidence.' Urban Policy and Research 20(4): 391-414. 
Commonwealth Grants Commission 2006a, Report on State Revenue Sharing Relativities 2006 Update. Commonwealth Grants Commission, Canberra.

2006b, Relative Fiscal Capacity of the States 2006. Commonwealth Grants Commission, Canberra.

Dahlby, B. 2001, Taxing Choices: Issues in the Assignment of Taxes in Federations. UNESCO, Paris.

Department of Transport and Regional Services 2005, Local Government National Report. 2003-04 Report on the Operation of the Local Government (Financial Assistance) Act 1995. Australian Government, Canberra. Accessible at http://www.dotars.gov.au

Devenson, I. 2006, 'One step from best in the world.' The Australian, 14/07.

Dixon, P.B., M.R.Picton M.T. and Rimmer 2002, 'Efficiency Effects of Intergovernmental Fiscal Transfers in Australia.' The Australian Economic Review, 35(3):304-15.

2005, 'Efficiency Effects of Changes in Commonwealth Grants to the States: A CGE Analysis'. Australian Economic Papers 44 : 82-104.

Dollery, B. 2005a, 'The State of Play in Australian Local Government' Working Paper Series in Economics, No. 2005-5, University of New England, Armidale.

2005b, 'A Critical Evaluation of Structural Reform Considerations in 'Rates and Taxes: A Fair Share for Responsible Local Government'. Australian Geographer, 36(3): 385-397.

2005c, 'Alternative Approaches to Structural Reform in Regional and Rural Australian Government' Paper presented at Dean's Lecture Series, La Trobe University, November.

Dollery, B. and L. Crase 2004a, 'Is Bigger Local Government Better? An evaluation of the economic case for Australian municipal amalgamation programs' Working Paper Series in Economics, No. 2004-4, University of New England, Armidale.

2004b, 'A Critical Note on 'Eco-Civic Regionalisation as the Basis for Local Government Boundaries in Australia.' Australian Geographical Studies 4I(3): 221-236.

Dollery, B., L. Crase and S. O'Keefe 2005, 'Improving Efficiency in Australian Local Government: Structural Reform as a Catalyst for Effective Reform.' Working Paper Series in Economics, No. 2005-16, University of New England, Armidale.

Dollery, B. and E. Fleming 2005, 'A Conceptual Note on Scale Economies, Size Economies and Scope Economies in Australian Local Government.' 
Working Paper Series in Economics, No. 2005-6, University of New England, Armidale.

Dollery, B. and A. Johnson 2005, 'Enhancing Efficiency in Australian Local Government: An Evaluation of Alternative Models of Municipal Governance.' Working Paper Series in Economics, No. 2005-1, University of New England, Armidale.

Dollery, B., A.Johnson, N. Marshall and A. Witherby 2005, 'ROCs Governing Frameworks for Sustainable Regional Economic Development: A Case Study.' Sustaining Regions, 4(3): 15-21

Dollery, B., C. Keogh and L. Crase 2005, 'Alternatives to Amalgamation in Australian Local Government: Lessons from the New Zealand Experience.' Working Paper Series in Economics, No. 2005-15, University of New England, Armidale.

Dollery, B., N. Marshall and T. Sorensen 2005, 'An Analytical Evaluation of New Models for Local Government Service Provision in Regional New South Wales.' Working Paper Series in Economics, No. 2005-12, University of New England, Armidale.

Drummond, M.L. 2001, 'Updated Estimates that Provide Stronger Support than ever for the Abolition of State Governments and a Move to a Better System of Government can Improve Australia's Situation to the Value of some $\$ 30$ billion per annum.' Accessible at http://www.asc.org.au/cost.htm

2002, 'Costing Constitutional Change: Estimating the Cost of Five Variations on Australia's Federal System.' Australian Journal of Public Administration 61(4): 43-56.

Frontier Centre for Public Policy 2003, Reassessing Local Government Amalgamation. Accessible at www.fcpp.org

Garnaut, R. and V. Fitzgerald 2002, Review of Commonwealth - State Funding. Final Report. Accessible at www.reviewcommstatefunding.com.au

Grewel, B. and P. Sheehan 2003, The Evolution of Constitutional Federalism in Australia: An Incomplete Contracts Approach. CSES Working Paper \#22, Victoria University, Melbourne.

Hall, R. 1998, Abolish the States! Australia's Future and a \$30 Billion Answer to our Tax Problems. Pan-Macmillan, Sydney.

Hancock, J. and J. Smith 2001, Financing the Federation. South Australian Centre for Economic Studies, Adelaide.

Harding, A., N.Warren, G. Beer, Phillips and K. Osei 2002, 'The Distributional Impact of Selected Commonwealth Outlays and Taxes and Alternative 
Grant Allocation Mechanisms.' The Australian Economic Review 35(3): 325-34.

House of Representatives Standing Committee on Economics, Finance and Public Administration 2003, Rates and Taxes: A Fair Share for Responsible Local Government. Parliament of the Commonwealth of Australia, Canberra.

Jaensch, D. 2003, 'Reforming Federalism?: A Discussion Paper.' Paper presented to Annual National Republican Convention. Accessible at http://www.republicans.org.au

Local Government Grants Commission South Australia 2005, Annual Report 20042005. Accessible at www.localgovt.sa.gov.au

Marshall, N. 1998, 'Reforming Australian local government: efficiency, consolidation - and the question of governance.' International Review of Administrative Sciences 64(4): 643-662.

Marshall, N., B. Dollery and A. Witherby 2003, 'Regional Organisation of Councils (ROCs): The Emergence of Network Governance in Metropolitan and Regional Australia?' Australasian Journal of Regional Studies 9(2), 169-187.

McLean, I. 2004, 'Fiscal Federalism in Australia.' Public Administration 2(1), 2138.

Morris, A. 2002, 'The Commonwealth Grants Commission and Horizontal Fiscal Equalisation.' The Australian Economic Review 35(3): 318-24.

National Commission of Audit 1996, Report to the Commonwealth Government. Accessible at http://www.finance.gov.au/bubs/ncoa.htm

New South Wales Local Government Grants Commission 2005, 2004-05 Annual Report. Accessible at www.dlg.nsw.gov.au

Northern Territory Grants Commission 2005, Annual Report 2004-05. Accessible at http://www.grantscommission.nt.gov.au

Oates, W.E. 1972, Fiscal Federalism. Harcourt Brace, New York.

Oates, W.E. 2005, 'Towards a Second Generation Theory of Fiscal Federalism.' International Tax and Public Finance 12: 349-373.

Organisation for Economic Cooperation and Development 2006, Economic Survey of Australia 2006: Fiscal Relations across Levels of Government. OECD, Paris.

Parliament of Victoria 1998, Report on Australian Federalism: The Role of the States. Accessible at http://www.parliament.vic.gov.au/fdrc/report 
Petchey, J. and S. Levtchenkova 2004, 'Fiscal Equalisation in Australia: Proposals for An Efficiency-Based System.' Economic Papers 23 (2): 189-200.

Productivity Commission 2005, Annual Report 2004-05. Productivity Commission: Canberra.

2006, Productive Reform in a Federal System: Roundtable Proceedings. Productivity Commission: Canberra.

Queensland Local Government Grants Commission 2005, Report for 2005. Accessible at www.qlggc.qld.gov.au

Regional Business Development Panel 2003, Regional Business: A Plan of Action. Report to the Department of Transport and Regional Services, Canberra.

Regional Implementation Working Group 2005, Regional Delivery of NRMMoving Forward, March.

Rouse, P. and M. Putterill 2005, 'Local Government Amalgamation Policy: A Highway Maintenance Evaluation' Management Accounting Research, I6: 438-463.

Sancton, A. 2005, 'The Governance of Metropolitan Areas in Canada' Public Administration and Development 25, 317-327.

Saunders, C. 2002, 'Collaborative Federalism.' Australian Journal of Public Administration 6I(2), 69-77.

Selway, B. 2001, 'The Federation - What makes it Work and What Should we be thinking about for the Future' Australasian Journal of Public Administration 6o(4): 116-122.

Soorley, J. 2004, 'Do We Need a Federal system? The Case for Abolishing State Governments', in W. Hudson and A. J. Brown (eds) Restructuring Australia: Regionalism, Republicanism and Reform of the Nation State. Federation Press, Sydney.

Soul, S.C. 2000, Population Size and Economic and Political Performance of Local Government Jurisdictions. Unpublished PhD thesis, Southern Cross University, Lismore.

Soul, S. and B. Dollery 2000, 'An Analysis of Criteria Used by Australian Government Amalgamation Inquiries Between 1960 and 1992' Working Paper Series in Economics, No. 2000-9, University of New England, Armidale.

State Chamber of Commerce (NSW) 2005, Local Government Enquiry Submission. State Chamber of Commerce NSW, Sydney.

Sydney Morning Herald 2006, 'Editorial: The time has come to shed a tier.' Sydney Morning Herald 10/2: 10. 
Tasmania. State Grants Commission 2005, Annual Report for 2005-06. Accessible at www.treasury.tas.gov.au

Tredbeck, D. and G. Cutbush 1996, 'Overlap and Duplication in Federal-State Relations.' Proceedings of the Seventh Conference of the Samuel Griffith Society, Adelaide, June. Accessible at http://www.samuelgriffith.org.au

Twomey, A. and G. Withers, 2007, Australia's Federal Future: Delivering Growth and Prosperity, Federalist Paper 1, Council for the Australian Federation.

Usher, D. 1995, The Uneasy Case for Equalization Payments. The Fraser Institute, Vancouver.

Victoria Grants Commission 2005, Annual Report 2004-05. Accessible at www.dvc.vic.gov.au

Warren, N. 2006, Benchmarking Australia's Intergovernmental Financial Relations. Interim Report to New South Wales Treasury, March.

Western Australian Local Government Grants Commission 2005, Annual Report 2005. Accessible at www.dlgrd.wa.gov.au/lggc/

Wilkins, R.B. 2004, 'Federalism: Distance and Devolution.' Australian Journal of Politics and History, 50(1): 95-101.

Williams, R.A. 2005, 'Federal-State Financial Relations in Australia: The Role of the Commonwealth Grants Commission.' The Australian Economic Review 38(1): 108-18.

2005, 'Fiscal Federalism: Aims, Instruments and Outcomes.' The Australian Economic Review 38(4): 351-69.

Williams, G. 2006, 'Federal System needs a new Deal.' The Courier Mail, 24/02

Woodbury, K., B. Dollery and P. Rao 2002, 'Local Government Efficiency and Management in Australia.' Working Paper Series in Economics, No. 20021, University of New England, Armidale.

Worthington, A. C. and B.E. Dollery 2000, 'Productive Efficiency and the Australian Government Grants Process: An Empirical Analysis of New South Wales Local Government.' Australasian Journal of Regional Studies 6(1), 95-121. 